\title{
Comparative Study on Pharmacognostical, Phytochemical Investigations and Quantification of Vasicine Content in the Extracts of Adhatoda vasica Nees and Adhatoda beddomei CB Clarke
}

\author{
Nandhini S', llango $K^{1,2, *}$
}

Nandhini S', llango $\mathbf{K}^{1,2, *}$

'Division of Pharmacognosy and Phytochemistry, Interdisciplinary Institute of Indian System of Medicine (IIISM), SRM Institute of Science and Technology, Kattankulathur - 603 203, Chengalpattu (Dt), Tamil Nadu, INDIA.

2Department of Pharmaceutical Chemistry, SRM College of Pharmacy, SRM Institute of Science and Technology, Kattankulathur603 203, Chengalpattu (Dt), Tamil Nadu, INDIA.

\section{Correspondence \\ Ilango Kaliappan}

Division of Pharmacognosy and

Phytochemistry, Interdisciplinary Institute of Indian System of Medicine (IIISM)

Department of Pharmaceutical Chemistry,

SRM College of Pharmacy SRM Institute of Science and Technology, Kattankulathur - 603 203, Chengalpattu (Dt), Tamil Nadu, INDIA

E-mail: ilangok67@gmail.com

History

- Submission Date: 12-04-2020;

- Review completed: 05-05-2020;

- Accepted Date: 13-05-2020;

DOI : 10.5530/pj.2020.12.126

Article Available online

http://www.phcogj.com/v12/i4

\section{Copyright}

(C) 2020 Phcogi.Com. This is an openaccess article distributed under the terms of the Creative Commons Attribution 4.0 International license.

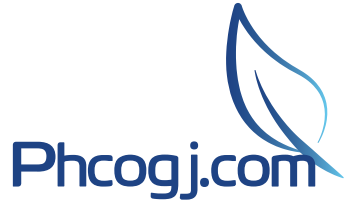

\begin{abstract}
Background: Adhatoda, a perennial shrub of family Acanthaceae are well-known medicinal plant for the treatment and management of respiratory disorders such as asthma and bronchitis. Adhatoda vasica and Adhatoda beddomei are the species of Adhatoda, has been widely used in Indian system of medicine. Although, phytochemical and pharmacological investigations were reported on $A$. vasica, there has been comparative investigations on different Adhatoda species are lacking. Objective: The study was undertaken to compare the pharmacognostical and phytochemical parameters of two species of Adhatoda for rapid identification and authentication of the plants. Materials and Methods: Pharmacognostical features were studied by macroscopic, microscopic studies and physicochemical analysis such as determination of foreign matter, ash value, extractive value and loss on drying. Phytochemical investigations were analysed using phytochemical screening, bioactive content determination, HPTLC fingerprint analysis and estimation of vasicine content by HPLC analysis. Results: Microscopic study differentiated the pharmacognostical features between two species by demonstrating the anatomical characteristics. Powder microscopy of $A$. vasica revealed the presence of diacytic stomata, glandular and non-glandular trichomes whereas rod shaped crystals were seen only in $A$. beddomei. Qualitative and quantitative phytochemical investigations revealed the presence and estimation of various phytoconstituents in both the species. HPTLC fingerprint profiling evaluated the number of constituents present in the extracts and HPLC analysis revealed high content of vasicine in A. vasica extracts when compared to $A$. beddomei. Conclusion: The present study provides the useful information to differentiate the plant species and can serve as a diagnostic tool for the standardization and identification of adulterant in the crude drug market.
\end{abstract}

Key words: Adhatoda vasica, Adhatoda beddomei, Pharmacognosy, HPTLC fingerprint, Vasicine.

\section{INTRODUCTION}

Herbal medicine is the oldest form of healing and treating various diseases. ${ }^{1}$ Herbal medicines have been widely used due to its more cost effective with no side effects when compared to synthetic drugs. About $80 \%$ of the world population rely mainly on herbal medicine for their primary health care. ${ }^{2}$ The increasing demand in the use of herbal medicine gain an attention of the researchers interestingly to study the standardization and quality control of herbal drugs in order to avoid the erroneous medication and improve the quality of drugs. Standardization is a significant tool for ensuring the quality of herbal drugs. The drug identity, purity, content, chemical and other biological properties determine the quality of the drug. ${ }^{3}$

Tropical species of the genus Adhatoda (Acanthaceae) commonly known as 'Vasa' in India have long been used for the treatment of cold, cough, asthma, bronchitis and tuberculosis. AdhatodavasicaNeesis a sub herbaceous widespread throughout the temperate regions of South Asia, ${ }^{4}$ used for more than 3000 years in Indian traditional medicine for the prevention, management and treatment of several illnesses and respiratory disorders viz., cold, severe cough, chronic bronchitis, asthma and tuberculosis ${ }^{5}$ etc. It is commonly known as vasaka or malabar nut tree. Adhatoda beddomei CB Clarke is one of the species of Adhatoda called as adalodakam in Tamil, rarely distributed in Western Ghats of Kerala and Tamil Nadu and used in Ayurveda, the ancient Indian System of Medicine (ISM). ${ }^{6}$ It has been the choice for the treatment and management of several diseases such as fever, cough, asthma, bronchitis, leprosy, blood disorders, heart troubles, inflammation, jaundice, tumors, and tuberculosis. ${ }^{78}$ Most of the pharmacognostic, phytochemical and pharmacological work of 'Vasa' carried out on Adhatoda vasica Nees..$^{9-11}$ It was reported as uterotonic, abortifacient, ${ }^{12}$ oxytocic, ${ }^{13}$ anti-inflammatory, ${ }^{14,15}$ due to the presence of vasicine content. The ministry of Ayush recommended to consume Kabasura kudineer as an ayurvedic preparation and Adathodai manapagu, a siddha remedy which contain $A$. vasica as one of the main

Cite this article: Nandhini S, llango K. Comparative Study on Pharmacognostical, Phytochemical Investigations and Quantification of Vasicine Content in the Extracts of Adhatoda vasica Nees and Adhatoda beddomei CB Clarke. Pharmacogn J. 2020;12(4):884-96. 
ingredients for the prevention and treatment of recently emerged respiratory infection, Covid-19. Earlier, these medications were used for the treatment of swine flu and dengue fever, respectively. ${ }^{16,17}$ Besides, Adhatoda beddomei also have been used for asthma by tribal in Kerala.

GC-MS fingerprint profiling of ethanolic extract of $A$. beddomei was reported and found to possess various volatile constituents ${ }^{8}$ and identification and quantification of alkaloids and flavonoids were also reported on these plants. ${ }^{18,19}$ Although, much phytochemical information about these plants were reported, there has been no evidence on pharmacognostical and comparative investigations with the plant $A$. beddomei, which can be a better alternative species for A. vasica. However, both the plants are closely related to each other and have similar morphological characteristics. The objectives of the present study were to evaluate the comparative pharmacognostical and phytochemical parameters of Adhatoda vasica and Adhatoda beddomei to elucidate the major differences between the two species of Adhatoda. Besides, an attempt has also been made to find out the presence or absence phytoconstituents and quantitative estimation of the pyrroquinazoline alkaloid, vasicine in both the species.

\section{MATERIALS AND METHODS}

\section{Collection and authentication of plant}

The leaves of Adhatoda vasica and Adhatoda beddomei were collected from Chengalpattu and Gingee Hills, Villupuram (Dt), respectively in the month of October 2017. The plants were authenticated by Prof. P. Jayaraman (Botanist), Plant Anatomy Research Centre (PARC), Tambaram, Chennai, Tamil Nadu, India with a reference number of $A$. vasica and A. beddomei was PARC/2018/3653 and PARC/2018/3654 respectively. The plant specimens were preserved in the Herbarium at Interdisciplinary Institute of Indian System of Medicine (IIISM), SRM Institute of Science and Technology, Kattankulathur, Chengalpattu, Tamil Nadu, India. Collected leaves were cleaned with a running tap water, dried under shade and powdered using cutter mill, sieved through 60 mesh sieve and stored in an airtight container at room temperature.

\section{Chemicals and reagents}

Analytical grade hexane, chloroform, ethyl acetate and methanol used for extraction were purchased from Ranchem Private Limited. Formic acid (analytical grade), methanol (HPLC grade) were procured from Ranchem Private Limited. Chemicals of analytical grade and other reagents were obtained from Merck Specialities Private Limited, Mumbai.

\section{Macroscopic analysis}

Sensory and macroscopic analysis of both the leaves of $A$. vasica and $A$. beddome $i$ were performed and the parameters evaluated for the fresh leaves were shape, size, colour, venation, apex, margin, base, texture, fracture,odour, taste, and petiole size.

\section{Microscopic study}

\section{Collection of Specimens}

The required samples of different organs were cut and removed from the plant and fixed in FAA (formaldehyde: alcohol: acetic acid, 10: 50: $5 \%$ with $35 \%$ water). After $24 \mathrm{~h}$ of fixing, the specimens were dehydrated with graded series of tert-butyl alcohol as per the schedule given by Sass, $1940 .^{20}$ Infiltration of the specimens was carried by gradual addition of paraffin wax (melting point $58-60^{\circ} \mathrm{C}$ ) until TBA solution attained super saturation. The specimens were cast into paraffin blocks.

\section{Sectioning}

The embedded paraffin wax was sectioned with the help of Rotary
Microtome. The thickness of the section was $10-12 \mu \mathrm{m}$. Dewaxing of the section was done by customary procedure. ${ }^{21}$ The sections were stained with Toluidine blue as per the method published by O'Brien et al1964. ${ }^{22}$ Since Toluidine blue is a polychromatic stain. The staining results were remarkably good; and some cytochemical reactions were also obtained. The dye rendered pink colour to the cellulose walls, blue to the lignified cells, dark green to suberin, violet to the mucilage, blue to the protein bodies etc. Wherever necessary sections were also stained with safranin and fast-green and iodine potassium iodide (for Starch).

For studying the stomatal morphology, venation pattern and trichome distribution, paradermal sections (sections taken parallel to the surface of leaf) as well as clearing of leaf with $5 \%$ sodium hydroxide or epidermal peeling by partial maceration employing Jeffrey's maceration fluid ${ }^{20}$ were prepared. Glycerin mounted temporary preparations were made for macerated/cleared materials. Powdered materials of different parts were cleared with $\mathrm{NaOH}$ and mounted in glycerin after staining. Different cell components were studied and measured.

\section{Photomicrographs}

Microscopic descriptions of tissues were supplemented with micrographs wherever necessary. Photographs of different magnifications were taken with Nikon Lab photo 2 microscopic Unit. For normal observations bright field was used. For the study of crystal, starch grains and lignified cells, polarized light was employed. Since these structures have birefringent property under polarized light, they appear bright against dark background. Magnifications of the figures are indicated by the scale-bars.

\section{Physicochemical analysis}

Physicochemical analysis such as the percentage of total ash, acidinsoluble ash, water-soluble ash, water and alcohol soluble extractives and loss on drying were determined according to WHO guidelines. ${ }^{23}$

\section{Preparation of extracts}

Each $5 \mathrm{~g}$ of powdered A. vasica and A. beddomei were extracted in $50 \mathrm{ml}$ of hexane, chloroform, ethyl acetate and methanol for $24 \mathrm{~h}$ at room temperature for non-successive extraction. The extracts were filtered and re-extracted thrice by following the same procedure. The filtrates were combined and concentrated under reduced pressure using a Buchi rotary evaporator.

\section{Phytochemical screening}

Phytochemical analysis was carried out for all the extracts according to standard methods ${ }^{24-26}$ (Table 1).

\section{Determination of bioactive contents}

\section{Determination of total alkaloid content (TAC)}

The extracts were prepared with $1 \mathrm{mg} / \mathrm{mL}$ of stock solution using $2 \mathrm{~N}$ hydrocholic acid. $1 \mathrm{~mL}$ of the solution from the stock was kept in a separating funnel and $1 \mathrm{~mL}$ of phosphate buffer of $\mathrm{pH} 4.7$ was added for the complex formation for $10 \mathrm{~min}$. The complex mixture was partitioned with $3 \mathrm{~mL}$ of chloroform and the chloroform layer was separated and diluted to $10 \mathrm{~mL}$ with chloroform. The absorbance of the mixture was measured at $415 \mathrm{~nm}$ using UV spectrophotometer. Results were expressed as $\mathrm{mg}$ of atropine equivalent in $\mathrm{g}$ of dry weight of the extract. ${ }^{27,28}$

\section{Determination of total phenolic content (TPC)}

The extract of $100 \mu \mathrm{L}$ solution were mixed with $3.5 \mathrm{ml}$ of distilled water and $1 \mathrm{~mL}$ of Folin-Ciocalteu reagent and kept aside for $8 \mathrm{~min}$. To this, $7.5 \%$ of $5 \mathrm{~mL}$ sodium carbonate was added and kept at room temperature for $30 \mathrm{~min}$ and the absorbance was measured at $765 \mathrm{~nm}$. Gallic acid was 
Table 1: Preliminary phytochemical screening test procedure.

\begin{tabular}{cccc}
\hline S. No & Phytoconstituents & Test & Observation \\
\hline 1 & Alkaloids & Mayer's Test & Yellow precipitate \\
2 & Glycosides & Liebermann Burchard test & Blue to green coloration \\
3 & Flavonoids & Lead acetate test & Yellow precipitate \\
4 & Terpenoids & Copper acetate test & Emerald green coloration \\
5 & Steroids & Salkowski test & Reddish brown at the junction \\
6 & Saponins & Froth test & Foam formation \\
7 & Amino acids & Ninhydrin test & Blue coloration \\
8 & Carbohydrates & Molisch's test & Violet ring formation at the junction \\
\hline
\end{tabular}

used as standard and the samples were analysed in triplicate. Total phenolic content was expressed as mg of gallic acid equivalent in $g$ of dry weight of the extract. ${ }^{29}$

\section{Determination of total flavonoid content (TFC)}

Total flavonoid content was carried out using Aluminium chloride colorimetric assay with slight modifications. ${ }^{30}$ The standard calibration curve was plotted with catechin solution $(20-100 \mu \mathrm{g} / \mathrm{mL})$. The extract of $100 \mathrm{uL}$ was mixed with $4 \mathrm{ml}$ of distilled water and $0.3 \mathrm{~mL}$ of $5 \%$ sodium nitrite. After $5 \mathrm{~min}, 0.3 \mathrm{~mL} 10 \%$ aluminium chloride solution was added and incubated for $5 \mathrm{~min}$ at room temperature. Finally, $2 \mathrm{~mL}$ of $0.1 \mathrm{M}$ sodium hydroxide was added and made upto $10 \mathrm{~mL}$ with distilled water. The formation of pink colour indicated that the formation of complex which further absorbed at 510nm using UV spectrophotometer against blank.

\section{Determination of total terpenoid content (TTC)}

Determination of terpenoid content was performed based on the method Ni et al 2012, with ursolic acid as a standard. ${ }^{31}$ Calibration curve was constructed using standard concentration of $20-20 \mu \mathrm{g} / \mathrm{mL}$. Initially, $1.5 \mathrm{~mL}$ of diluted extract was evaporated to dryness at $100^{\circ} \mathrm{C}$ in a water bath. To the dried residue, $2.5 \mathrm{ml}$ of vanillin in acetic acid and $4 \mathrm{~mL}$ of glacial acetic acid were added and cooled the solution at room temperature for $15 \mathrm{~min}$. The final mixture was absorbed at $548 \mathrm{~nm}$ against a blank solution using UV spectrophotometer. The terpenoid content was expressed in $\mathrm{mg}$ of ursolic acid equivalent in $\mathrm{g}$ of dry weight of the extract.

\section{Determination of total glycoside content (TGC)}

The estimation of glycoside content was carried out using a Baljet reagent according to the method described in Solich et al $1992 .{ }^{32} 1 \mathrm{~mL}$ of extract was added to the solution of Baljet reagent containing picric acid and $0.1 \mathrm{~N}$ sodium hydroxide with the ratio of $95: 5$. The solution was allowed to incubate in a dark chamber for $60 \mathrm{~min}$ and the solution was further diluted to $15 \mathrm{~mL}$ with distilled water and absorbed at $495 \mathrm{~nm}$. Digitoxin was used as a standard for the determination of glycoside and the results were expressed in $\mathrm{mg}$ of digitoxin equivalent to $\mathrm{g}$ of dry weight of the extract.

\section{Determination of total steroidal content (TSC)}

The determination of steroidal content was carried out according to Liebermann-Burchard colorimetric assay method ${ }^{33}$ with minor modification using cholesterol as a standard. The LiebermannBurchard reagent was prepared by adding $5 \mathrm{ml}$ of concentrated sulphuric acid to $50 \mathrm{~mL}$ of acetic anhydride solution. The extracts were diluted with chloroform and to the chloroform extract, freshly prepared Liebermann-Burchard reagent was added and measured at $650 \mathrm{~nm}$ against a reagent blank. Steroidal content was expressed in $\mathrm{mg}$ of cholesterol equivalent to $g$ of dry weight of the extract.

\section{Determination of total saponin content (TSAC)}

The total saponin content was determined based on $\mathrm{Xu}$ and Chang
2009 , using diosgenin as a standard solution. ${ }^{34} 1 \mathrm{~mL}$ of $80 \%$ aqueous methanol was added to $1 \mathrm{~mL}$ of diluted extracts followed by $1 \mathrm{~mL}$ of Vanillin reagent and $1 \mathrm{~mL}$ of $72 \%$ sulphuric acid were added to the sides of the tubes. The mixture was heated on a water bath $60^{\circ} \mathrm{C}$ for $10 \mathrm{~min}$ and the absorbance was recorded at $544 \mathrm{~nm}$ against $80 \%$ methanol as blank. The saponin content was calculated using standard calibration curve of diosgenin with a concentration range of $20-200 \mu \mathrm{g} / \mathrm{mL}$ solution and the results were expressed in $\mathrm{mg}$ of diosgenin equivalent to $\mathrm{g}$ of dry weight of the extract.

\section{Sample preparation}

The extracts of leaves of A. vasica and A. beddomei (each 100mg) were dissolved in $1 \mathrm{~mL}$ of methanol and sonicated for $15 \mathrm{~min}$. The extracts were filtered and made upto $1 \mathrm{~mL}$ with methanol and stored in a refrigerator until further use.

\section{HPTLC Fingerprinting Analysis}

High performance thin layer chromatography (HPTLC) method was performed on pre-coated HPTLC aluminium sheets silica gel $60 \mathrm{~F}$ 254 plate $(10.0$ X10.0 cm) of $250 \mu \mathrm{m}$ thickness (Merck, Darmstadt, Germany). The plates were pre-washed with methanol and then activated at $100^{\circ} \mathrm{C}$ for $15 \mathrm{~min}$ before use. The prepared sample solutions of $2 \mu \mathrm{L}$ were spotted as $6.0 \mathrm{~mm}$ narrow bands using $100 \mu \mathrm{L}$ syringe at a constant dosing speed of $150 \mathrm{~nL} / \mathrm{s}$ with a Linomat V semi-automatic applicator (Camag, Muttenz, Switzerland). The HPTLC plate was developed at a distance of $70 \mathrm{~mm}$ in a $10.0 \times 10.0 \mathrm{~cm}$ twin trough chamber using a pre saturated mobile phase of hexane: ethyl acetate: formic acid $(6: 4: 0.1 \mathrm{v} / \mathrm{v} / \mathrm{v})$. The developed TLC plate was dried using hot air for a minute and visualized under $254 \mathrm{~nm}, 366 \mathrm{~nm}$ and white light using TLC Visualizer. Further, the plate was scanned at the wavelength of 366nm using a TLC Scanner 180712 (Camag) with winCATS Planar Chromatography Manager software.

\section{Quantification of Vasicine by RP-HPLC-PDA}

RP-HPLC-PDA method was developed for the quantification of vasicine using Shimadzu LC-20AD HPLC system equipped with CT0$20 \mathrm{~A}$ controller and the column oven. A Rheodyne 7725 injection valve with $20 \mu \mathrm{L}$ loop volume, an SPD-M20A photo-diode array detector and a Lab solution 7.1 version software was used for data acquisition and interpretation. Chromatographic separation was achieved on Agilent $\mathrm{C}_{18}$ column ( $150 \mathrm{~mm} \times 4.6 \mathrm{~mm} ; 3 \mu \mathrm{m}$ pore size). The solvent mixture of $0.1 \% \mathrm{v} / \mathrm{v}$ trifluoroacetic acid (A) and methanol: acetonitrile (45:40) (B) with a ratio of $(70: 30 \% \mathrm{v} / \mathrm{v})$ at a flow rate $0.6 \mathrm{~mL} / \mathrm{min}$, the column was maintained at room temperature and the PDA detector was fixed at $280 \mathrm{~nm}$.

\section{RESULTS AND DISCUSSION}

\section{Macroscopy}

Adhatoda vasica and Adhatoda beddomei are sub-herbaceous shrub of family Acanthaceae. Adhatoda vasica, an evergreen, gregarious perennial shrub, 1.2 to $6 \mathrm{~m}$ in height, distributed throughout India, 
up to an altitude of $1300 \mathrm{~m}$. Leaves were elliptical lanceolate or ovate lanceolate in shape, entire, crenate margin and symmetric base, $5-30 \mathrm{~cm}$ long, hairy, light green in colour at the upper surface and dark green in colour at the lower surface with characteristic odour. A. beddomei, a glaborous shrub of 1 to $3 \mathrm{~m}$ in height rarely found in higher altitudes of Western Ghats of Kerala and Tamil Nadu. The leaf was simple, entire, wavy, ovate lanceolate in shape, attenuate at base and acuminate apex, 6 to $14 \mathrm{~cm}$ long and 3 to $4.5 \mathrm{~mm}$ broad with prominent midrib at the lower surface. Odour was not characteristic and slightly bitter in taste.

Macroscopic characters were studied, compiled and presented in Table 2.

\section{Microscopy}

\section{Transverse section of midrib-entire view}

In transectional view, the midrib of $A$. vasica showed bowl-shaped and thick in abaxial part with short thick two adaxial humps and a shallow median concavity (Figure 1a). In A. beddomei, the leaf appeared dorsiventral with thick midrib and bilateral lamina. The midrib was plano-convex in sectional view with semicircular abaxial part and slightly raised adaxial part with slightly wide and shallow adaxial cavity (Figure $1 \mathrm{~b}$ ). The midrib of $A$. vasica and $A$. beddomei were measured $1.3 \mathrm{~mm}$ and $1.15 \mathrm{~mm}$ in vertical plain and $1.5 \mathrm{~mm} 1.75 \mathrm{~mm}$ in horizontal plain, respectively. The adaxial epidermis of the midrib in A. beddomei consisted of small epidermal cells with minute papillate outer tangential walls which was similar to abaxial epidermis consisted of 3 or 4 layers of small thick-walled cells. The remaining ground tissue include, large thin walled, angular or circular, compact parenchyma cells. The lamina of $A$. vasica occured in vertical plain on either side of the midrib. The midrib consisted of thin epidermal layer on both adaxial and abaxial sides. Inner to the epidermis is a thick layer of sclerenchyma cells on the abaxial part. The ground parenchyma in the midrib contained circular thin walled compact parenchyma cells.
The vascular system A. vasica and A. beddomei showed a wide bowlshaped main vascular strand and one circular adaxial lateral vascular bundle on either side of the vascular arc (Figure 2) and a median wide cup-shaped main vascular strand, respectively. The main vascular arc consisted of several radial compact xylem elements each row comprising 4 or 5 xylem elements. The xylem elements were circular and thick walled. Along the lower surface of the arc occurs thick continuous layer of phloem elements in A. vasica (Figure 2a). The lateral margins of the main vascular strand of $A$. beddomei had separate vascular strands, (Figure 2b) there are 2 small circular independent vascular bundles located in the lower part of the adaxial ridge.

The adaxial lateral smaller bundles of $A$. vasica were circular with thick cluster of xylem elements surrounded by small distinct phloem elements. The xylem elements were angular wide and thick walled. The vascular strand was surrounded by thin layer of fibers (Figure $3 \mathrm{a}$ and Figure $3 \mathrm{~b}$ ).The vascular strands of $A$. beddomei were collateral with lower compact xylem elements and thick layer of continuous phloem elements which extend all along the lower surface of the vascular strand. The vascular bundles of the adaxial region were circular with compact mass of thick-walled xylem elements and a layer of phloem elements (Figure $3 \mathrm{c}$ ). The vascular strands have a thin layer of bundle sheath sclerenchyma.

\section{Lamina}

The lamina of $A$. vasica was dorsiventral with distinction into adaxial and abaxial sides. The lamina was smooth and even on both surfaces of A. beddomei. The lamina was $270 \mu \mathrm{m}$ thick. Adaxial epidermal cells were larger, cubical and thin walled. The abaxial epidermal cells were smaller and rectangular in shape in A. vasica whereas the adaxial epidermal cells and abaxial epidermal cells were circular or squarish and thin walled in A. beddomei. The adaxial epidermal cells contained a prominent cuticle in $A$. beddomei.

Table 2: Comparative macroscopic features of the leaves of Adhatoda vasica and Adhatoda bedddomei.

\begin{tabular}{ccc}
\hline Particulars & Adhatoda vasica & Adhatoda beddomei \\
\hline Colour & Dark green colour & Green colour \\
Odour & Characteristic & Not characteristic \\
Taste & Bitter & Slightly bitter \\
Habit & Dense shrub & Glaborous shrub \\
Shape & Ovate lanceolate & Elliptic lanceolate \\
Size & Length: $10-16 \mathrm{~cm}$ & Length: $6-14 \mathrm{~cm}$ \\
& Width: $3-4 \mathrm{~cm}$ & Width: $3-4.5 \mathrm{~cm}$ \\
Margin & Crenate to entire & Entire \\
Base & Symmetric & Attenuate \\
\end{tabular}
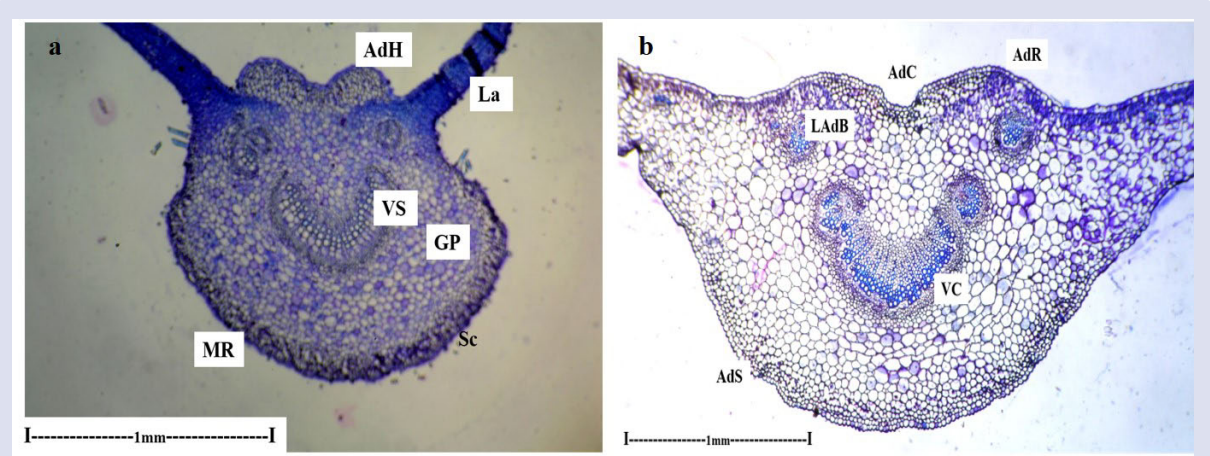

Figure 1: Transverse section of midrib under low magnification; a) Adhatoda vasica; b) Adhatoda beddomei (AdH-Adaxial Hump; AdS- Adaxial Side; AdC- Adaxial Cavity; AdR- Adaxial Ridge; LAdB- Lateral Adaxial Bundle; La- Lamina; MR- Midrib; GP- Ground Parenchyma; VS- Vascular strand). 


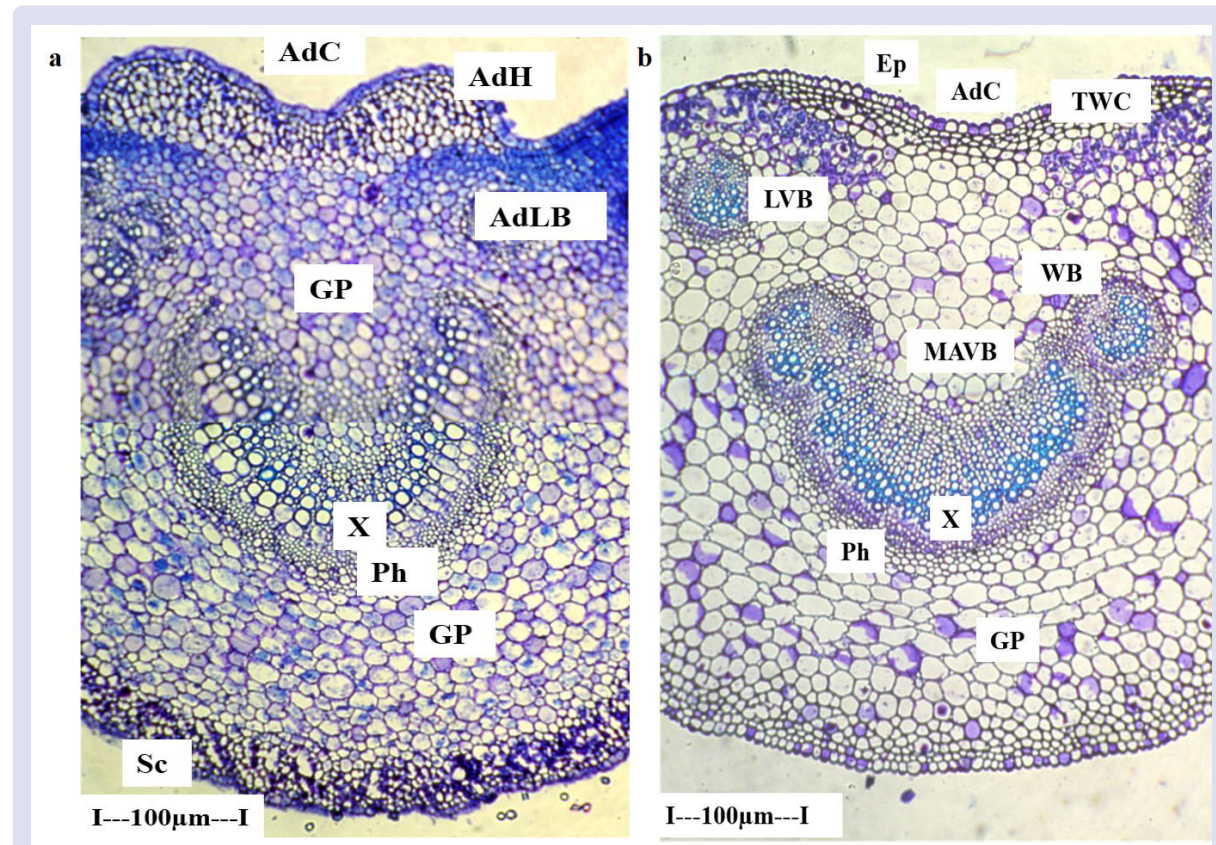

Figure 2: Transverse section midrib -Central portion enlarged; a) Adhatoda vasica; b) Adhatoda beddomeim (AdH-Adaxial Hump; AdC- Adaxial Cavity; AdR- Adaxial Ridge; AdLB- Adaxial Lateral Bundle; MAVB- Median Adaxial Vascular Bundle; Ep- Epidermis; LVB- Lateral Vascular Bundle; TWC-Thick Walled Cells; WB- Wing Bundle; GP- Ground Parenchyma; Ph-Phloem; Sc-Sclerenchyma; X-Xylem).

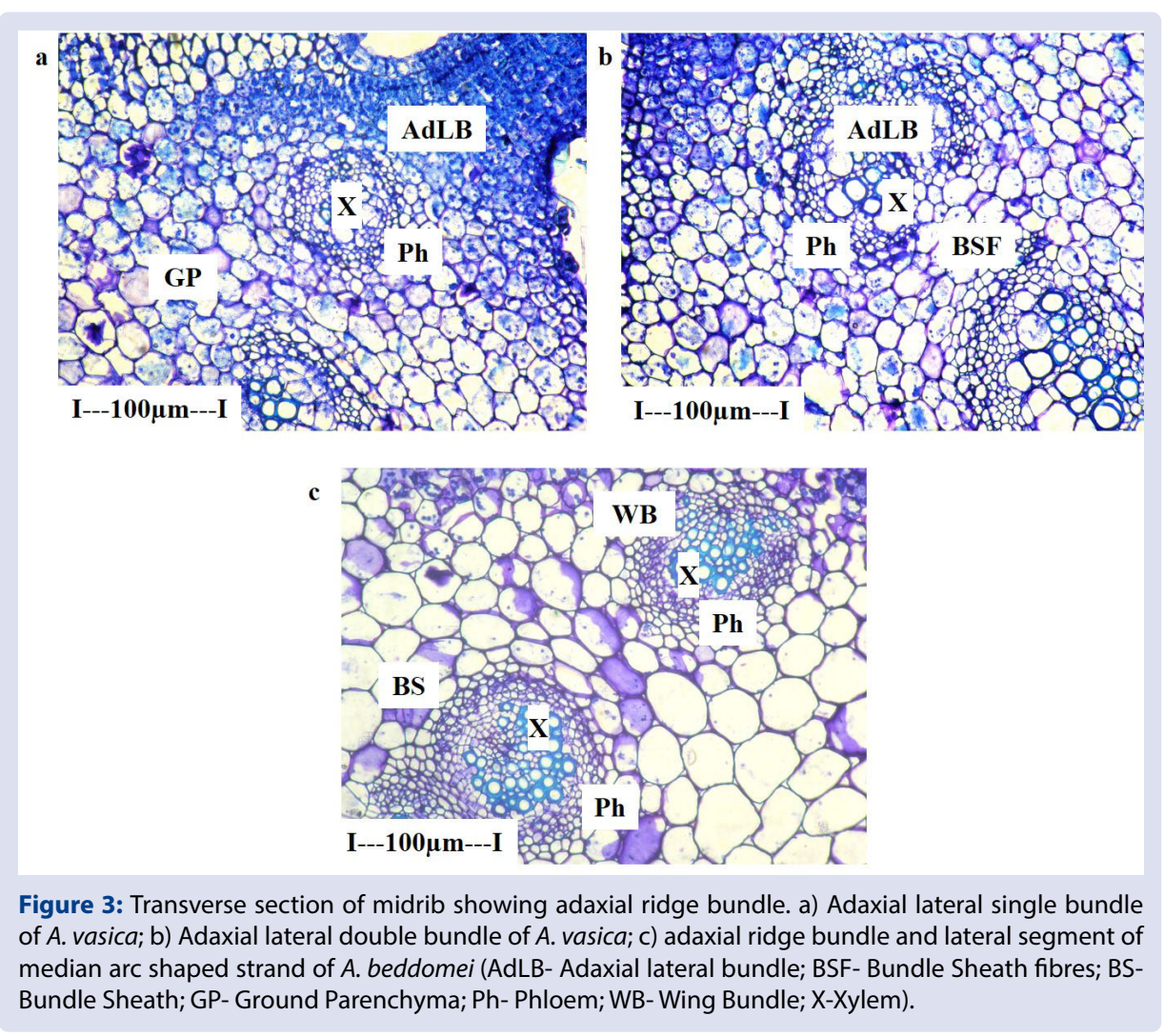


The mesophyll tissue of $A$ vasica was differentiated into adaxial band of thick rectangular palisade mesophyll cell and abaxial zone of 4 or 5 layers of large spherical spongy mesophyll cells. The mesophyll tissue consisted of an abaxial band of 2 short, cylindrical palisade mesophylls were seen in A. beddomei. Small air chambers were present in the spongy mesophyll zone of $A$. vasica (Figure 4a) and the spongy mesophyll was circular, intercellular air space with stomata occurred on the abaxial epidermal layer of $A$. beddomei (Figure $4 \mathrm{~b}$ ).

\section{Epidermal trichomes}

In A. vasica, two types of epidermal trichomes were arised from epidermal cells. Some are non-glandular type which are multicellular, uniseriate and unbranched. The cells of the trichome were vertically elongated and thin walled. These trichomes were $150 \mu \mathrm{m}$ long and $15 \mu \mathrm{m}$ thick (Figure 5a) and glandular trichomes have short stalk cell with which it was attached on the epidermis (Figure 5b). The upper secretary body was two celled with dense accumulation of cell inclusions. The glandular trichomes was $10 \mu \mathrm{m}$ broad and $15 \mu \mathrm{m}$ in height.
In A. beddomei, short prominent glandular trichomes were seen on the abaxial epidermal layer. The trichome was buried in the shallow epidermal cavity which were multicellular and funnel shaped. The cells were darkly stained and the gland was at the level of epidermal layer (Figure 5c).

\section{Crystal distribution}

In the mesophyll tissues of $A$. beddomei, calcium oxalate crystals were seen which was absence in $A$. vasica. The crystals may be raphide type consisting of several thin needles (Figure 6a) or it could be rectangular long crystals were aggregated in the form of circular cluster (Figure 6b).

\section{Powder microscopy}

\section{Trichomes}

Adhatoda vasica were observed with more non glandular covering type of trichomes on the leaf, stem and petiole surfaces and less frequent glandular trichomes. The non-glandular trichomes were long,
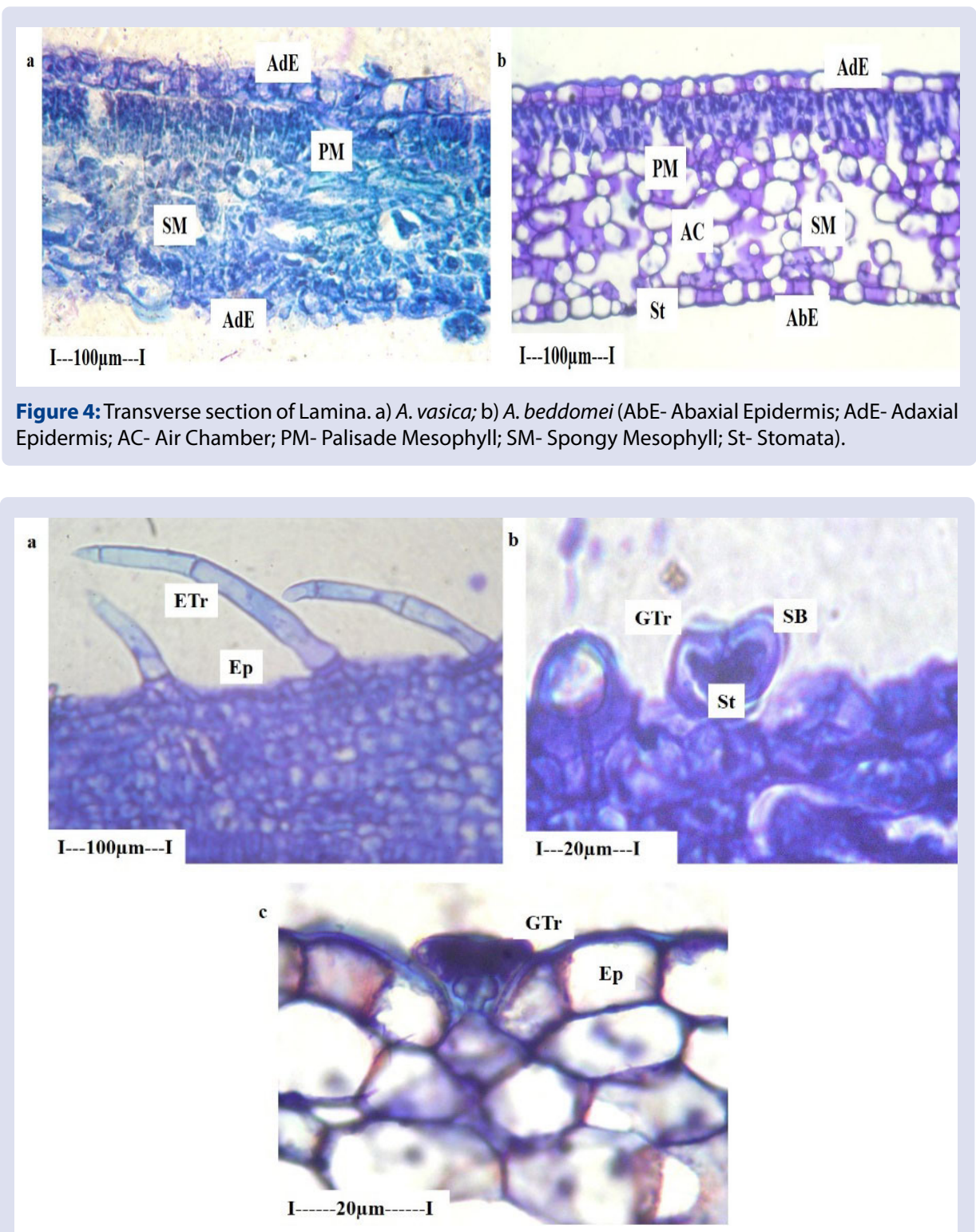

Figure 5: Transverse section of lamina with glandular and non-glandular trichomes; a) Non-glandular trichome of $A$. vasica; b) Glandular trichome of $A$. vasicaand c) Glandular trichome buried in the epidermal cavity of A. beddomei (Ep- Epidermis; GTr- Glandular Trichomes; Etr- Epidermal Trichomes; SB- Secretary Body; St- Stalk). 
multicellular, unbranched with thick walls and tapering ends (Figure 7a). The cells of the trichomes are vertically elongated with wide lumen. The trichomes were $130 \mu \mathrm{m}$ long and $10 \mu \mathrm{m}$ thick (Figures $7 \mathrm{a}$ and $7 \mathrm{c}$ ). The glandular trichomes were large, spherical, multicellular (usually 4 celled) secretory head with dense cytoplasm. The gland was subsessile with very short, non-glandular stalk. The glandular head may be $80 \mu \mathrm{m}$ in diameter and capitate type (Figure 7d).

In $A$. beddomei,short prominent glandular trichomes were seen on the abaxial epidermal layer with multicellular and funnel shaped. The cells were darkly stained and the gland was at the level of epidermal layer (Figure 8).

\section{Stomata}

The adaxial epidermis of both $A$. vasica and $A$. beddomei were apostomatic (without stomata). The abaxial epidermis were densely stomatiferous in nature. The stomata of both the species were diacytic type and the guard cells were enclosed with two unequal subsidiary cells with their common walls situated at right angles to long axis of the stoma (Figures $7 \mathrm{~b}$ and $8 \mathrm{c}$ ). The guard cells were levelly elliptical in shape and measured $10 \times 25 \mu \mathrm{m}$ and $35 \times 60 \mu \mathrm{m}$ size in A. vasica and $A$. beddomei, respectively. The abaxial epidermal cells were lobed with their anticlinal walls with thin or thick and slightly wavy. Stomata were densely distributed and they are random in orientation.

\section{Physicochemical analysis}

Physicochemical analysis was studied and represented with standard deviation in Table 3. Different physicochemical parameters studied were within permissible limits according to the Pharmacopoeial standards. The total, water soluble and acid insoluble ash of $A$. vasica and $A$. beddomei was found to be $12.85,3.17,0.95 \% \mathrm{w} / \mathrm{w}$ and $13.20,2.68$, $0.62 \% \mathrm{w} / \mathrm{w}$, respectively. The water soluble and alcohol soluble extractive were found to be 28.53 and $23.99 \% \mathrm{w} / \mathrm{w}$ for $A$. vasica and 22.17 and $6.12 \% \mathrm{w} / \mathrm{w}$ for $A$. beddomei. 5.77 and $7.80 \%$ of loss on drying was found in A. vasica and A. beddomei, correspondingly.
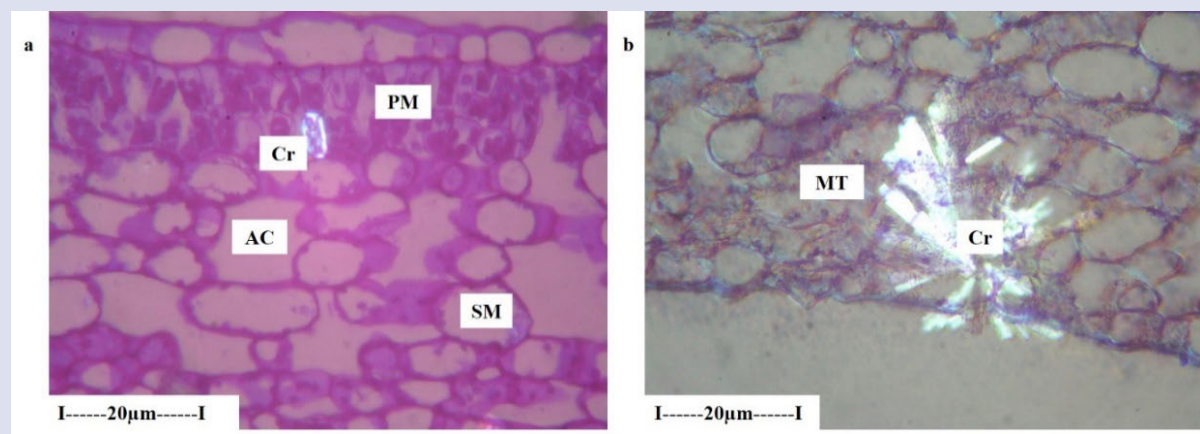

Figure 6: Crystal distribution in A. beddomei; a) Transverse section of leaf showing calcium oxalate crystal in the palisade zone. (under polarized light); b) Circular cluster of rod-shaped crystals in the spongy mesophyll tissue (AC- Air Chamber; Cr- Crystal; MT- Mesophyll Tissue; PM- Palisade Mesophyll; SM- Spongy Mesophyll).

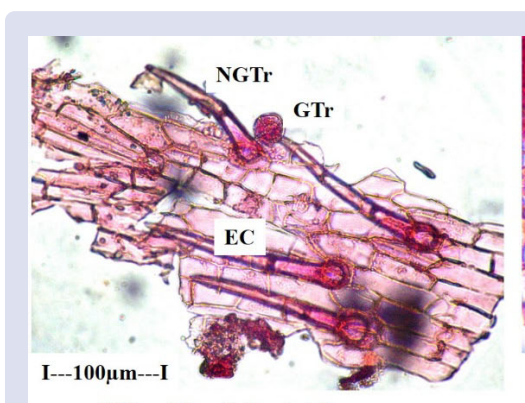

a) Non Glandular trichomes

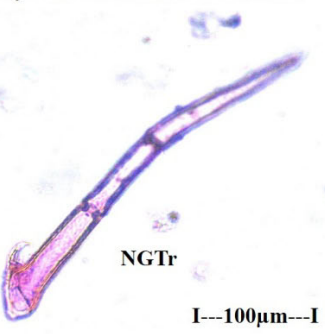

c) Non Glandular trichomes

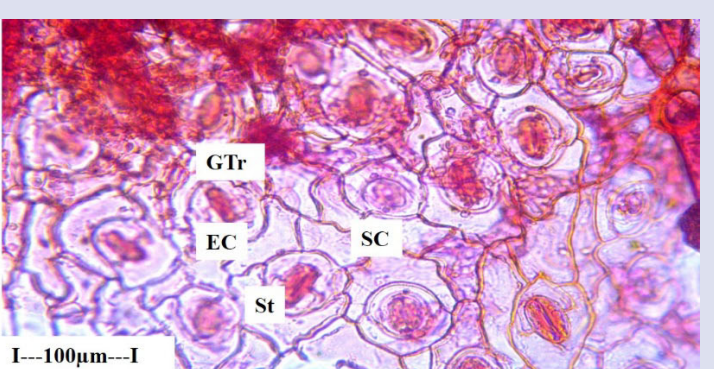

b) Diacytic stomata

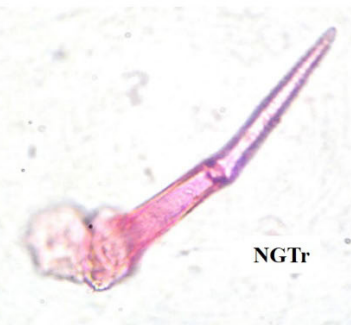

GT

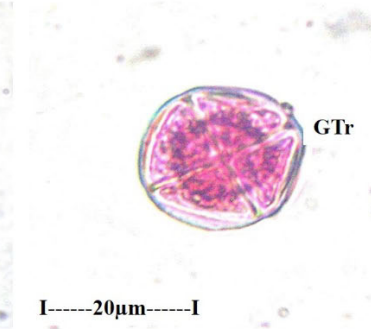

d) Glandular trichomes

Figure 7. a) Non glandular epidermal trichomes on the surface of the stem; b) Abaxial epidermis showing diacytic type of stomata; c) Non glandular Trichomes; d) Glandular Trichomes- the Secretory head (EC- Epidermal Cells; Gtr- Glandular Trichomes; NGTr- Non-glandular Trichomes; SC- Subsidiary Cells; St- Stoma). 


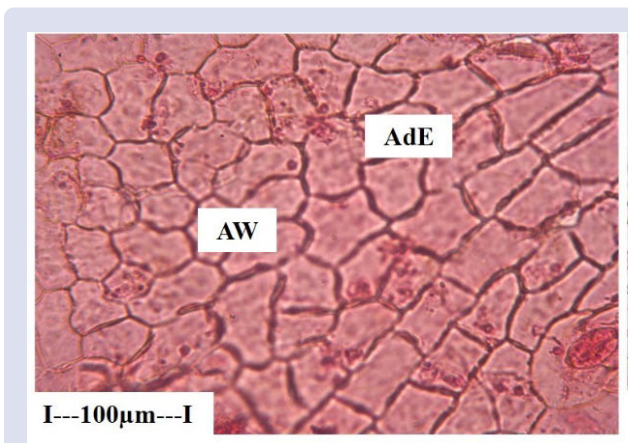

a) Epidermal peeling of Adaxial Epidermis

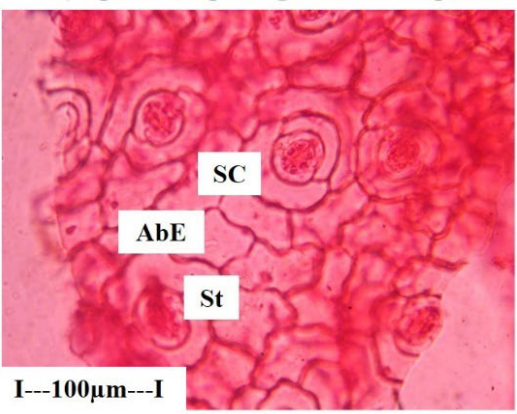

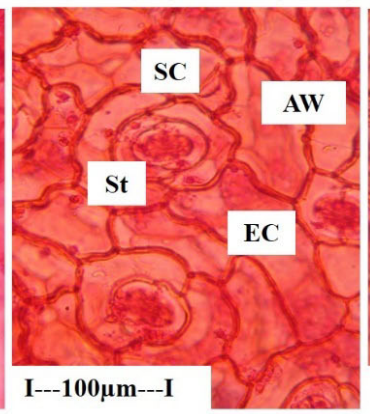

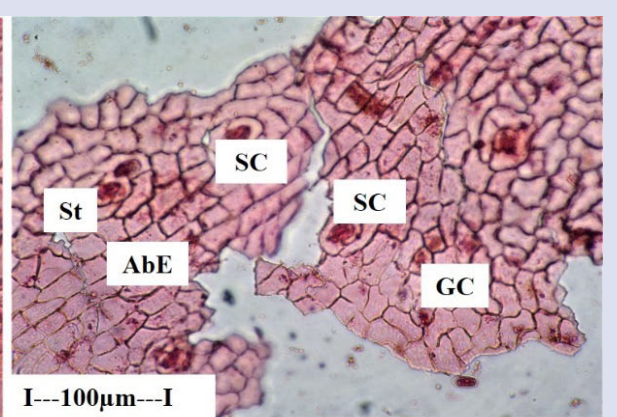

Abaxial Epidermis

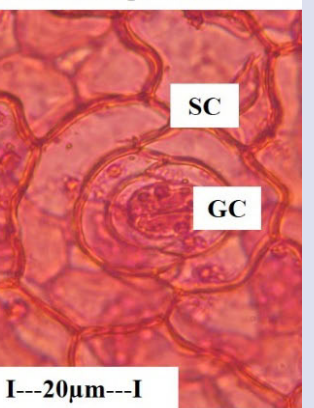

c) Abaxial epidermis showing thin and thick call walls and Diacytic stomata

Figure 8: a) Epidermal peeling of the adaxial epidermis; b) Epidermal peeling of the abaxial epidermis with stomata; c) Abaxial epidermis showing thin and thick call walls and diacytic subsidiary cells (AbEAbaxial Epidermis; AdE-Adaxial Epidermis; EC-Epidermal Cells; AW- Anticlinal Walls; GC- Guard Cells; SCSubsidiary Cells; St- Stomata).

Table 3: Proximate analysis of Adhatoda vasica and Adhatoda beddomei.

\begin{tabular}{ccc}
\hline Parameters & A. vasica & A. beddomei \\
\hline Foreign Organic Matter (\%) & 0.53 & 0.20 \\
Total Ash (\%w/w) & $12.85 \pm 0.52$ & $13.20 \pm 0.31$ \\
Acid-insoluble ash (\%w/w) & $0.95 \pm 0.06$ & $0.62 \pm 0.03$ \\
Water soluble ash $(\% \mathrm{w} / \mathrm{w})$ & $3.17 \pm 0.49$ & $2.68 \pm 0.25$ \\
Water soluble extractive value $(\% \mathrm{w} / \mathrm{w})$ & $28.53 \pm 0.42$ & $22.17 \pm 0.36$ \\
Alcohol soluble extractive value $(\% \mathrm{w} / \mathrm{w})$ & $23.99 \pm 0.29$ & $6.12 \pm 0.21$ \\
Loss on drying at $105^{\circ} \mathrm{C}$ & $5.77 \pm 0.37$ & $7.80 \pm 0.40$ \\
\hline
\end{tabular}

Values were in mean \pm standard deviation, $\mathrm{n}=3$

\section{Phytochemical screening}

The phytochemical examination revealed the presence of various phytoconstituents such as alkaloids, flavonoids, steroids, terpenoids and glycosides in of $A$. vasica and A. beddomei (Table 4).

\section{Determination of bioactive contents}

The bioactive content of total alkaloid, phenolic, flavonoid, terpenoid, glycoside, sterol, and saponin were determined in the extracts of $A$. vasica and A. beddomei and the results were depicted in Table 5. The content of alkaloid, phenol, flavonoid, glycoside, sterol and saponins were present in high concentration in A. vasica extracts whereas the terpenoid content were approximately similar in both the plant species.

The alkaloid content of the extracts was expressed as atropine equivalent and it was varied from $3.48 \mathrm{mg} / \mathrm{g}$ to $238.05 \mathrm{mg} / \mathrm{g}$ in $A$. vasica extracts. A. vasica extracts was found to contain a value of total phenolic (6.15 to $19.25 \mathrm{mg} / \mathrm{g}$ ), flavonoid ( 13.12 to $48.33 \mathrm{mg} / \mathrm{g})$, terpenoid $(4.85$ to $20.27 \mathrm{mg} / \mathrm{g}$ ), glycoside $(7.74$ to $195.19 \mathrm{mg} / \mathrm{g}$ ), saponin $(0.26$ to $2.97 \mathrm{mg} / \mathrm{g}$ ). The steroidal content was found to be high concentration in hexane extract as $51.98 \mathrm{mg} / \mathrm{g}$ whereas $42.10 \mathrm{mg} / \mathrm{g}$ in methanolic extract of A. vasica. In case of A. beddomei, the alkaloid content was found to be $171.84 \mathrm{mg} / \mathrm{g}$ and $195.72 \mathrm{mg} / \mathrm{g}$ in ethyl acetate and methanolic extract which was lesser than A. vasica extracts and in hexane and chloroform extract not in detectable limit. The other contents such as phenolic, flavonoid, terpenoid, glycoside and saponin contents for A. beddomei extracts were found to be in the range from 4.73 to $10.13 \mathrm{mg} / \mathrm{g}, 6.98$ to $26.62 \mathrm{mg}$.g, 10.83 to $19.48 \mathrm{mg} / \mathrm{g}, 15.34$ to $160.13 \mathrm{mg} / \mathrm{g}$ and 0.16 to $0.87 \mathrm{mg} / \mathrm{g}$ respectively. The steroidal content of $A$. beddomei was found to be high concentration in hexane extract as $27.69 \mathrm{mg} / \mathrm{g}$ whereas $22.09 \mathrm{mg} / \mathrm{g}$ in methanolic extract. High concentration of bioactive compounds was found in A. vasica when compared to A. beddomei extracts.

\section{HPTLC fingerprinting analysis}

HPTLC fingerprint profiling of Adhatoda species were developed with different mobile phases in order to obtain high resolution and peak reproducibility. The phytocompounds were eluted with a mobile phase consisting of hexane, ethyl acetate and formic acid with a ratio of $6: 4: 0.1 \mathrm{v} / \mathrm{v} / \mathrm{v}$. Visual examination of obtained chromatogram (Figure 9) revealed a difference in the chemical composition of various extract of Adhatoda. The fingerprinting analysis revealed the presence of 3, 9, 7 and 5 spots in hexane, chloroform, ethyl acetate and methanolic extracts respectively in A. vasica extract. In case of A. beddomei, 1, 5, 7 
and 4 spots were obtained. The extracts of $A$. vasica consisted of more phytocompounds when compared to A. beddomei extracts (Figure 10).

\section{Quantification of Vasicine by RP-HPLC-PDA}

Vasicine, a principal bioactive marker has extensively used as a potential bronchodilator. HPLC-PDA method was developed for the estimation of vasicine using a mobile phase of $0.1 \% \mathrm{v} / \mathrm{v}$ trifluoroacetic acid (A) and methanol: acetonitrile $(45: 40)(B)$ with a ratio of $(70: 30 \% \mathrm{v} / \mathrm{v})$. Linearity graph (Figure 11) was plotted from the concentration range from 20 $120 \mu \mathrm{g} / \mathrm{mL}$ with $\mathrm{y}=29487 \mathrm{x}-88941$ and regression coefficient of 0.998 . The retention time of vasicine was found to be $3.946 \mathrm{~min}$. The HPLC chromatogram of vasicine standard and different extracts of Adhatoda species were shown in Figure 12.

The hexane, chloroform, ethyl acetate and methanolic extract of $A$. vasica and A. beddomei revealed that the content of vasicine as 0.143 , $0.907,1.672,2.051 \mathrm{mg} / \mathrm{g}$ and $0.042,0.077,0.165$ and $0.475 \mathrm{mg} / \mathrm{g}$, respectively (Table 6).The high amount of vasicine $(2.051 \mathrm{mg} / \mathrm{g})$ was found in methanolic extract of A. vasica when compared to other extracts, whereas in methanolic extract of $A$. beddomei, was found to be $0.475 \mathrm{mg} / \mathrm{g}$ which was lesser than $A$. vasica extracts.

The comparative pharmacognostical studies revealed that, the morphological and microscopical differences in the Adhatoda species viz, A. vasica and $A$. beddomei. There were no crystals seen in A. vasica, where as rod shaped crystals were observed in the leaves of $A$. beddomei. Powder microscopic study showed the difference in epidermal trichomes. The presence of non-glandular trichomes were seen in the leaves of A. vasica, which was absent in A. beddomei. Diacytic stomata were seen in both the species of Adhatoda. The total, water soluble and acid insoluble ash of $A$. vasica was found to be $12.85,3.17,0.95 \% \mathrm{w} / \mathrm{w}$ respectiively. The water soluble and alcohol soluble extractive were found to be 28.53 and $23.99 \% \mathrm{w} / \mathrm{w}$ respectively for A. vasica and loss on drying was found to be $5.77 \%$. A. vasica was found to contain more water soluble, acid insoluble ash and extractive values and $A$. beddomei was found to contain more total ash and loss on drying.

Table 4: Preliminary phytochemical screening of $A$. vasica and $A$. beddomei.

\begin{tabular}{|c|c|c|c|c|c|c|c|c|}
\hline \multirow{2}{*}{ Phytochemical Tests } & \multicolumn{4}{|c|}{ Adhatoda vasica } & \multicolumn{4}{|c|}{ Adhatoda beddomei } \\
\hline & Hexane & Chloroform & Ethyl acetate & Methanol & Hexane & Chloroform & Ethyl acetate & Methanol \\
\hline Alkaloids & - & - & + & +++ & - & - & + & ++ \\
\hline Glycosides & - & - & - & + & - & - & - & + \\
\hline Saponins & - & - & + & ++ & - & - & + & + \\
\hline Phytosterols & +++ & + & + & + & +++ & + & + & + \\
\hline Flavonoids & + & + & ++ & ++ & + & + & ++ & ++ \\
\hline Terpenoids & ++ & + & + & ++ & ++ & + & + & + \\
\hline Phenols & + & + & ++ & ++ & + & + & ++ & ++ \\
\hline
\end{tabular}

(+)- Low; (++)- Medium; (+++)- Strong; (-)- Absence

Table 5: Estimation of bioactive content ( $\mathrm{mg} / \mathrm{g})$ in $A$. vasica and A. beddomei by UV Spectrophotometer.

\begin{tabular}{|c|c|c|c|c|c|c|c|}
\hline $\begin{array}{l}\text { Quantitative } \\
\text { Parameters }\end{array}$ & Alkaloids & Phenolics & Flavonoids & Terpenoids & Glycosides & Steroids & Saponins \\
\hline AV-Hexane & $3.48 \pm 0.002$ & $6.15 \pm 0.0002$ & $13.12 \pm 0.0003$ & $4.85 \pm 0.005$ & $7.74 \pm 0.004$ & $51.98 \pm 0.0004$ & $0.26 \pm 0.001$ \\
\hline AV-Chloroform & $42.92 \pm 0.001$ & $7.96 \pm 0.0002$ & $15.42 \pm 0.0004$ & $5.21 \pm 0.01$ & $18.68 \pm 0.01$ & $49.51 \pm 0.0005$ & $0.60 \pm 0.001$ \\
\hline AV-Ethyl acetate & $176.4 \pm 0.005$ & $18.56 \pm .0003$ & $39.27 \pm 0.0002$ & $12.19 \pm 0.01$ & $112.27 \pm 0.001$ & $46.00 \pm 0.0004$ & $2.08 \pm 0.004$ \\
\hline AV-Methanol & $238.05 \pm 0.003$ & $19.25 \pm 0.0003$ & $48.33 \pm 0.0003$ & $20.27 \pm 0.003$ & $195.19 \pm 0.004$ & $42.10 \pm 0.0003$ & $2.97 \pm 0.004$ \\
\hline AB-Hexane & ND & $4.73 \pm 0.0004$ & $6.98 \pm 0.0004$ & $10.83 \pm 0.01$ & $15.34 \pm 0.02$ & $27.96 \pm 0.0004$ & ND \\
\hline AB-Chloroform & ND & $6.18 \pm 0.0004$ & $11.87 \pm 0.0006$ & $15.54 \pm 0.01$ & $16.66 \pm 0.0004$ & $25.36 \pm 0.0003$ & $0.16 \pm 0.006$ \\
\hline AB-Ethyl acetate & $171.84 \pm 0.001$ & $8.64 \pm 0.0002$ & $15.78 \pm 0.0005$ & $18.04 \pm 0.005$ & $119.78 \pm 0.007$ & $24.14 \pm 0.0007$ & $0.48 \pm 0.01$ \\
\hline AB-Methanol & $195.72 \pm 0.002$ & $10.13 \pm 0.0004$ & $26.62 \pm 0.0001$ & $19.48 \pm 0.005$ & $160.13 \pm 0.01$ & $22.09 \pm 0.0002$ & $0.87 \pm 0.006$ \\
\hline
\end{tabular}

Values were in mean \pm standard deviation, $n=3$, ND- Not Detected

Alkaloids equivalent to Atropine, phenolics equivalent to Gallic acid, flavonoids equivalent to Catechin, terpenoids equivalent to Ursolic acid, glycosides equivalent to Digitoxin, steroids equivalent to Cholesterol and saponins equivalent to Diosgenin.

AV- Adhatoda vasica; AB- Adhatoda beddomei
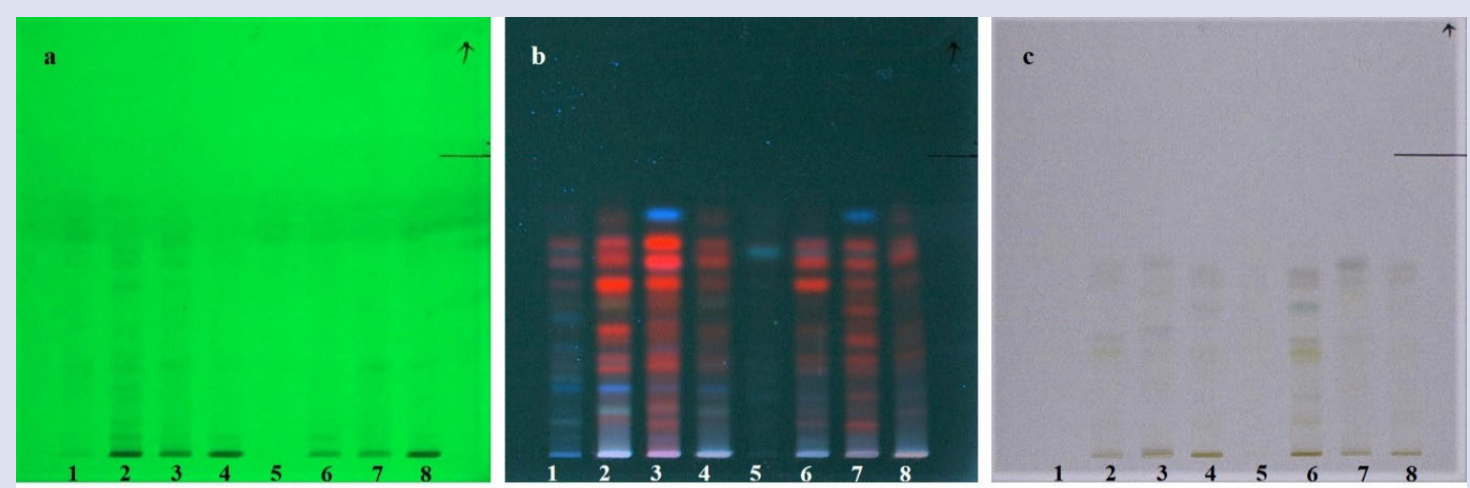

Figure 9: HPTLC chromatogram of Adhatoda species; Adhatoda vasica- Hexane, Chloroform, Ethyl acetate and Methanol (1-4) and Adhatoda beddomei- Hexane, Chloroform, Ethyl acetate and Methanol (5-8); a) $254 \mathrm{~nm}$; b) $366 \mathrm{~nm}$ and c) White light. 


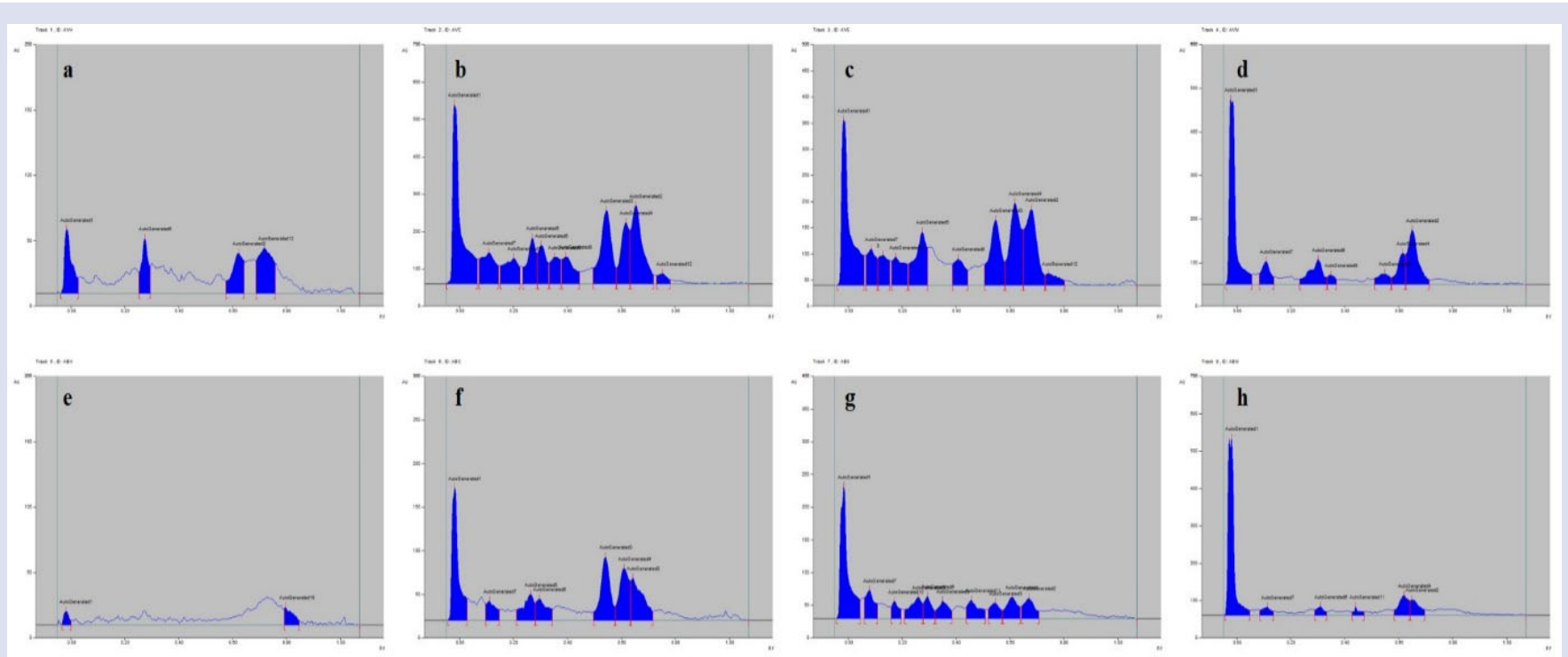

Figure 10: HPTLC densitometric chromatogram of Adhatoda species at 366nm; Adhatoda vasica- Hexane, Chloroform, Ethyl acetate and Methanol (a-d) and Adhatoda beddomei- Hexane, Chloroform, Ethyl acetate and Methanol (e-h).

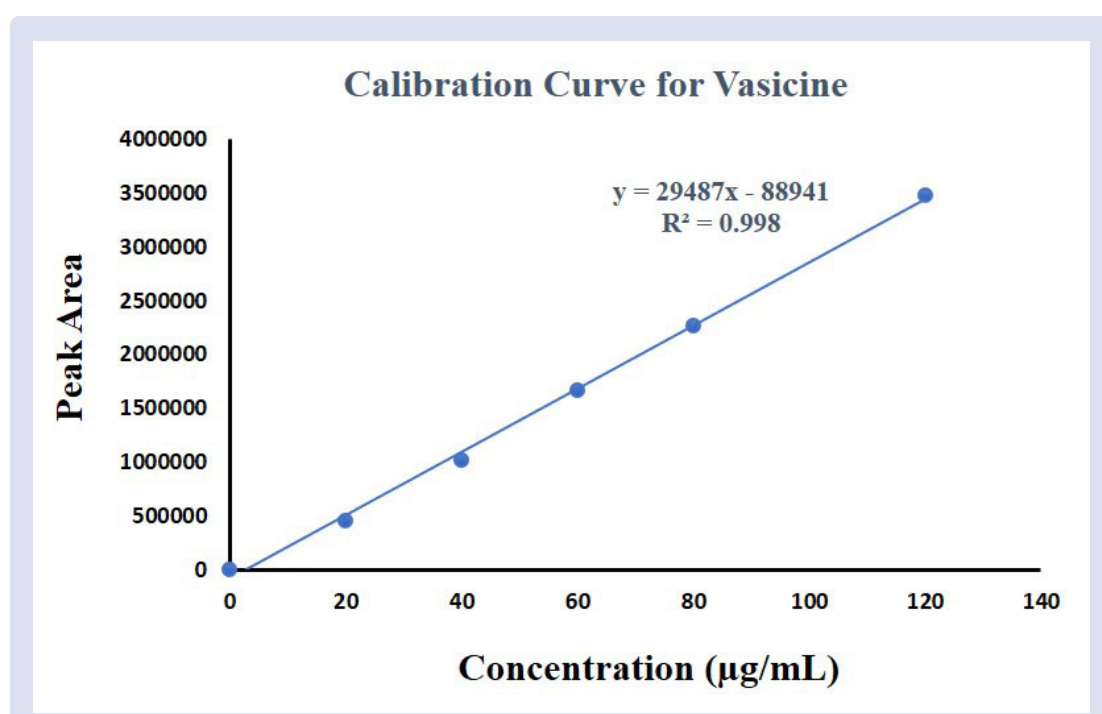

Figure 11: Calibration curve of vasicine standard in the concentration range $20-120 \mu \mathrm{g} / \mathrm{mL}$.

Table 6: Quantification of Vasicine in Adhatoda species.

\begin{tabular}{ccccccccc}
\hline \multirow{2}{*}{$\begin{array}{c}\text { Marker } \\
\text { compound }\end{array}$} & Hexane & Chloroform & Ethyl acetate & Methanol & Hexane & Chloroform & Ethyl acetate & Methanol \\
\cline { 2 - 9 } Vasicine $(\mathbf{m g} / \mathbf{g})$ & 0.143 & 0.907 & 1.672 & 2.051 & 0.042 & 0.077 & 0.165 & 0.475 \\
\hline
\end{tabular}

The preliminary phytochemical screening revealed the presence of more number of phytoconstituents in methanolic extracts of leaves of A. vasica, which was further confirmed by estimation of crude bioactive content. The total alkaloid, phenolic, flavonoid, terpenoid, glycoside and saponin contents were found to be more concentration in polar when compared to non-polar solvents with the order methanol> ethyl acetate $>$ chloroform $>$ hexane, whereas high concentration of steroids was found in non-polar solvents. HPTLC fingerprint profiling revealed that, the chloroform extracts of $A$. vasica showed a larger number of phytoconstituents when compared to other extracts and also in $A$. beddomei. HPLC analysis revealed the presence of high content of vasicine in methanolic extracts of $A$. vasica $(2.051 \mathrm{mg} / \mathrm{g})$ whereas $A$. beddomei contains only $0.475 \mathrm{mg} / \mathrm{g}$, which was found to be 5 times lesser than the methanolic extracts of $A$. vasica.

\section{CONCLUSION}

Standardization of herbal medicine is a key importance in establishing its proper identity, purity, quality and therapeutic efficacy. The macroscopic, microscopic, physicochemical and phytochemical analysis are the confirmatory test for standardization and quality control. Microscopic, pharmacognostical, preliminary phytochemical screening provides relevant information which may be helpful in authentication of crude drug and checking the adulteration of raw material. Microscopic studies differentiate the difference in the anatomical features and 


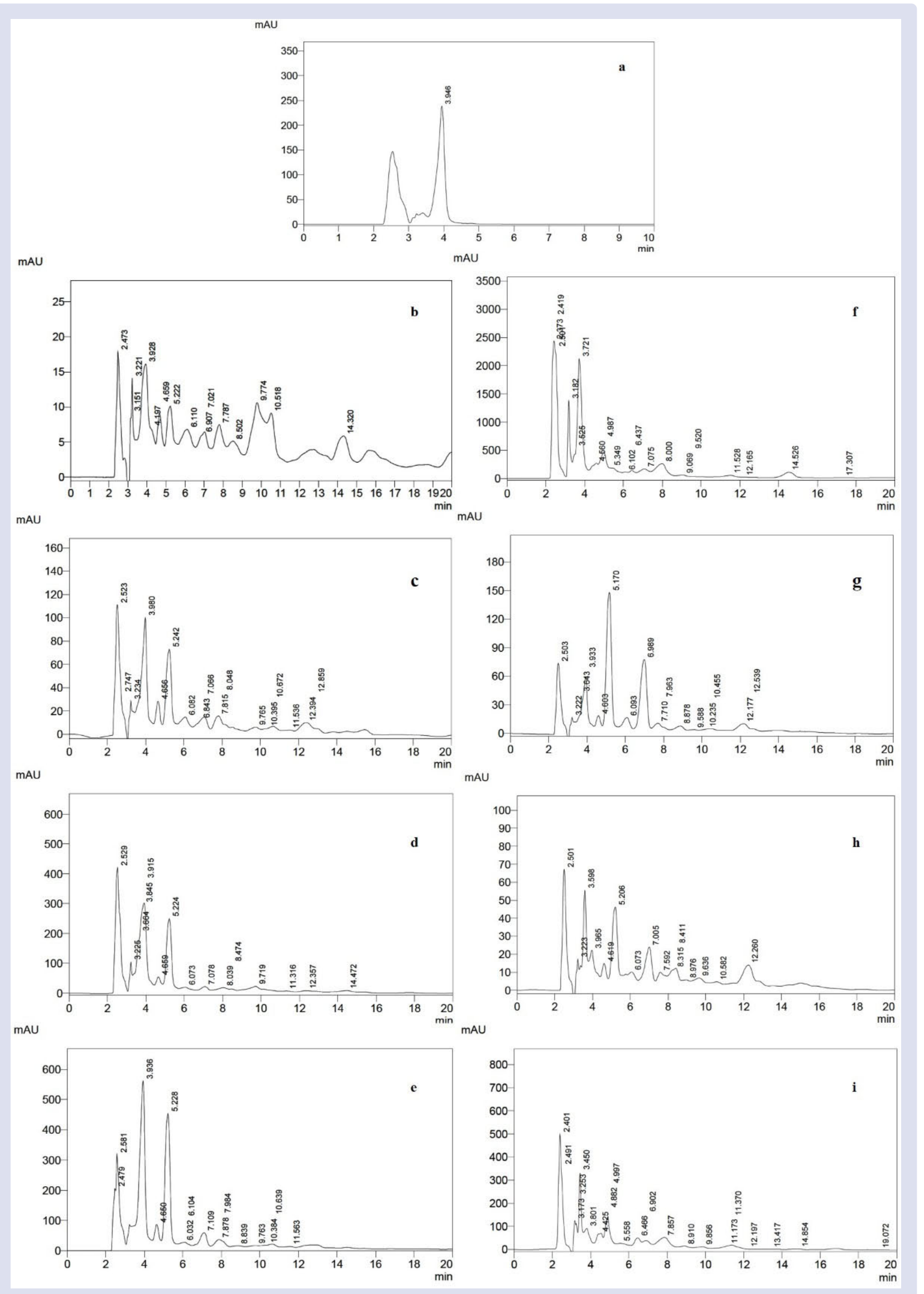

Figure 12: HPLC chromatogram of Adhatoda species; Vasicine standard (a); Adhatoda vasica- Hexane, Chloroform, Ethyl acetate and Methanol (b-e) and Adhatoda beddomei- Hexane, Chloroform, Ethyl acetate and Methanol (f-i). 
physicochemical parameters showed a major difference between the two plants. Phytochemical screening revealed the presence of various constituents and estimation of bio active compounds confirmed the high concentration of all the bioactive contents in A. vasica when compared to A. beddomei. HPTLC serves as an important and powerful tool for standardization which confirms the species of the herbal drugs and HPLC analysis provides a useful information on vasicine content of Adhatoda species. Vasicine estimation also revealed that high concentration in A. vasica extracts when compared to A. beddomei extracts which enables the differentiation between two species. Both HPTLC fingerprint analysis and HPLC quantification report further confirmed the availability of more amounts of phytoconstituents in $A$. vasica. The pharmacognostical study of $A$. beddomei and the comparative study of both $A$. vasica and $A$. beddomei were reported for the first time which helps in differentiating the plant from other species and useful for the identification and standardization. Although, the plant $A$. beddomei could be used in Kerala for medicinal purpose, the high content of phytoconstituents was observed in A. vasica. In conclusion, the present study can be used as a reference information for proper identification, authentication, collection and investigations of Adhatoda species to enhance the therapeutic efficacy in the treatment.

\section{CONFLICTS OF INTEREST}

None.

\section{ABBREVIATIONS}

A. vasica and AV-Adhatoda vasica; A. beddomei and AB- Adhatoda beddomei; FAA- Formaldehyde, Alcohol, Acetic acid; HPTLC- High performance thin layer chromatography; ISM- Indian System of Medicine;PARC- Plant anatomy research centre; RP-HPLC-PDAReverse phase high performance liquid chromatography-photodiode array; TBA- tert-butyl alcohol; TAC- Total alkaloidal content; TPCTotal phenolic content; TFC- Total flavonoid content; TTC- Total terpenoid content; TGC- Total glycoside content; TSC- Total steroidal content; TSAC- Total saponin content.

\section{REFERENCES}

1. Younis NA. The Prevalence, Attitude and Awareness of Herbal Medicine Products Use Among Pharmacy Practitioner in Jordan. Pharmacog J. 2019;11(5):1082-7.

2. Herbal Medicine Market Research Report - Global Forecast till 2023. https:// www.marketresearchfuture.com/reports/herbal-medicine-market-3250.

3. Ong ES.Extraction methods and chemical standardization of botanicals and herbal preparations. J Chromatogr B. 2004;812(1-2):23-33.

4. Hossain MT, Hoq MO. Therapeutic use of Adhatoda vasica. Asian J Med Biol Res. 2016;2(2):156-63.

5. Rao KV, Munjal M, Patnayak A, Karthik L, Kumar G. Phytochemical composition, antioxidant, antimicrobial and cytotoxic potential of methanolic extracts of Adhatoda vasica (Acanthaceae). Res J Pharm Tech. 2013;6(9):1004-9.

6. Abhyankar G, Reddy VD. Rapid micropropagation via axillary bud proliferation of Adhatoda vasica Nees from nodal segments. Ind J Exp Biol. 2007;45:268-71.

7. Dhuley JN. Antitussive effect of Adhatoda vasica extract on mechanical or chemical stimulation-induced coughing in animals. J Ethnopharmacol. 1999;67(3):361-5

8. Srinivasan M, Padmaja B and Nair S. GC-MS profiling and in vitro radical scavenging effect of Adhatoda beddomei. J Pharmacog Phytochem. 2014b;2:55-9.

9. Shah UR, Shah RG, Acharya NS, Acharya SR. Comparative pharmacognostic study of leaves of Adhataoda vasica and Ailanthus excelsa. Int J Pharmacog. 2014;1(2):95-8
10. Unnati S, Shilpa T, Daxa T, Mehul B. Pharmacognostical and phytochemical evaluation of Adhatoda vasica leaf. Int J Res Stud Biosci. 2014;2(11):144-8.

11. Sharma A, Kumar A. Pharmacognostic studies on medicinal plants: Justicia adhatoda. World J Pharm Res. 2016;5:1674-704.

12. Gupta OP, Anand KK, Ghatak BJ, Atal CK. Vasicine, alkaloid of Adhatoda vasica a promising uterotonic abortifacient. Indian J Exp Biol. 1978;16(10):1075-7.

13. Atal CK. Chemistry and pharmacology of vasicine - a new oxytocic and abortifacient. Indian Drugs. 1980;15(2):15-8.

14. Chakraborty A, Brantner AH. Study of alkaloids from Adhatoda vasica Nees on their anti-inflammatory activity. Phytother Res. 2001;15(6):532-4.

15. Srinivasarao D, Jayarraj IA, Jayarraj R, Prabha ML. A study on antioxidant and anti-inflammatory activity of vasicine against lung damage in rats. Ind J Allergy Asthma Immunol. 2006:20(1):1-7.

16. Saravanan J, Devasia N, Gopalasatheeskumar K, Sanish Devan V, Thanga Kokila K, Sanjay M. Anti-Inflammatory, Antipyretic and Antibacterial Study of Kabasura kudineer choornam. Int J Curr Adv Res. 2018;7(2):9992-7.

17. Kalaiarasi R, Jeeva Gladys R, Elangovan S, Soundararajan DK, Mubarak $H_{\text {, }}$ Kanakarajan A. A combination of nilavembu kudineer and adathodai manapagu in the management of dengue fever. Int J Curr Res. 2013;5(4):978-81.

18. Singh A, Kumar S, Reddy TJ, Rameshkumar KB, Kumar B. Screening of tricyclic quinazoline alkaloids in the alkaloidal fraction of Adhatoda beddomei and Adhatoda vasica leaves by high performance liquid chromatography/electrospray ionization quadrupole time of flight tandem mass spectrometry. Rapid Commun Mass Spectrom. 2015; 29(6):485-496.

19. Singh A, Kumar S, Bajpai V, Kumar B. Simultaneous determination of pyrroquinazoline alkaloids and flavonoids in Adhatoda beddomei and Adhatoda vasica and their marketed herbal formulations using ultra-high-performance liquid chromatography coupled with triple quadrupole linear ion trap mass spectrometer. Biomed Chromatogr. 2017;31(3):3827.

20. Sass JE. Elements of botanical microtechnique. Elements of botanical microtechnique. 1940.

21. Johansen DA. Plant microtechnique. Plant microtechnique. 1940.

22. O'Brien T, Feder N, McCully ME. Polychromatic staining of plant cell walls by toluidine blue O. Protoplasma. 1964;59(2):368-73.

23. WHO-Quality control methods for Herbal materials, I WHO Press, World Health Organization, 1211 Geneva 27, Switzerland. 2011;pp.5-27.

24. Ariharan VN, Prasad PN. Quantitative phytochemical analysis on leaf extract of Aegle marmelos. J Chem Pharm Res. 2014;6(3):1100-4

25. Yadav M, Chatterji S, Gupta SK, Watal G. Preliminary phytochemical screening of six medicinal plants used in traditional medicine. Int J Pharm Pharm Sci. 2014;6(5):539-42

26. Widjajakusuma EC, Jonosewojo A, Hendriati L, Wijaya S, Surjadhana A, Sastrowardoyo W, Monita N, Muna NM, Fajarwati RP, Ervina M, Esar SY Phytochemical screening and preliminary clinical trials of the aqueous extract mixture of Andrographis paniculata (Burm. f.) Wall. ex Nees and Syzygium polyanthum (Wight.) Walp leaves in metformin treated patients with type 2 diabetes. Phytomedicine. 2019;55:137-47.

27. Shamsa F, Monsef H, Ghamooshi R, Verdian-rizi M. Spectrophotometric determination of total alkaloids in some Iranian medicinal plants. Thai J Pharm Sci. 2008;32:17-20.

28. RaoTM, Rao BG, Rao YV. Antioxidant activity of Spilanthes acmella extracts. Int J Phytopharm. 2012;3(2):216-20.

29. McDonald S, Prenzler PD, Antolovich M, Robards K: Phenolic content and antioxidant activity of olive extracts. Food Chem. 2001;73(1):73-84.

30. Chang CC, Yang MH, Wen HM and Chern JC. Estimation of total flavonoid content in propolis by two complementary colorimetric methods. J Food Drug Anal. 2002;10(3):178-82.

31. Ni Q, Xu G, Wang Z, Gao Q, Wang S, Zhang Y. Seasonal variations of the antioxidant composition in ground bamboo Sasaargentea striatus leaves. Int J Mol Sci. 2012;13(2):2249-62.

32. Solich P, Sedliakova V, Karlíček R. Spectrophotometric determination of cardiac glycosides by flow-injection analysis. Anal Chim Acta. 1992;269(2):199-203.

33. Kim E, Goldberg M. Serum cholesterol assay using a stable LiebermannBurchard reagent. Clin Chem. 1969;15(12):1171-79.

34. Xu B, Chang SK. Phytochemical profiles and health-promoting effects of coolseason food legumes as influenced by thermal processing. JAgrFood Chem. 2009;57(22):10718-31. 


\section{GRAPHICAL ABSTRACT}

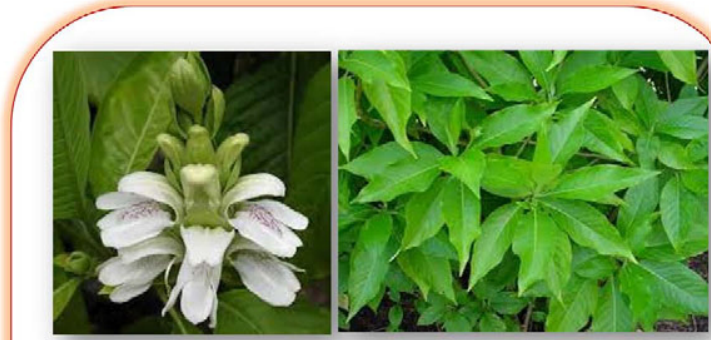

Adhatoda vasica Nees
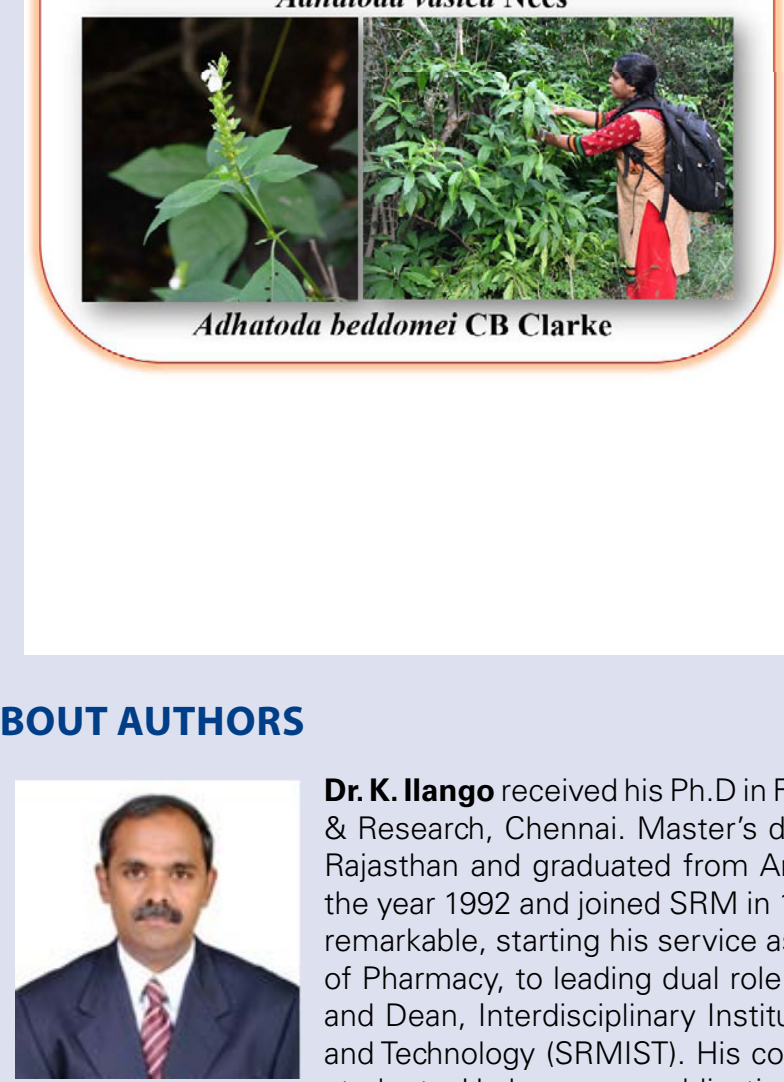

\section{ABOUT AUTHORS}

Dr. K. Ilango received his Ph.D in Faculty of Pharmacy from Sri Ramachandra Institute Higher education \& Research, Chennai. Master's degree from Birla Institute of Technology and Science (BITS), Pilani, Rajasthan and graduated from Annamalai University, Chidambaram. His teaching career started in the year 1992 and joined SRM in 1994. Since then, Dr. K. Ilango's involvement in academics had been remarkable, starting his service as Head the Department of Pharmaceutical Chemistry, SRM College of Pharmacy, to leading dual role at present as Professor, Department of Pharmaceutical Chemistry and Dean, Interdisciplinary Institute of Indian System of Medicine (IIISM) SRM Institute of Science and Technology (SRMIST). His contribution and sharing of knowledge has benefited several aspiring students. He has many publications in peer reviewed journals and having published several books and Indian patents to his credit.

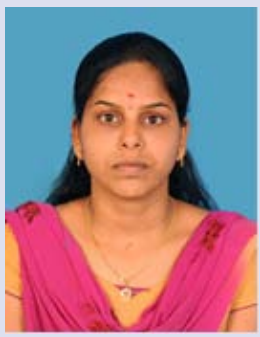

Ms.S.Nandhini has completed her Bachelors of Pharmacy and Masters of Pharmacy (Pharmacognosy) from Madras Medical College, Chennai. She is currently pursuing PhD under the guidance of Dr.K.Ilango at IIISM, SRM Institute of Science and Technology, Chennai.

Cite this article: Nandhini S, Ilango K. Comparative Study on Pharmacognostical, Phytochemical Investigations and Quantification of Vasicine Content in the Extracts of Adhatoda vasica Nees and Adhatoda beddomei CB Clarke. Pharmacogn J. 2020;12(4):884-96. 